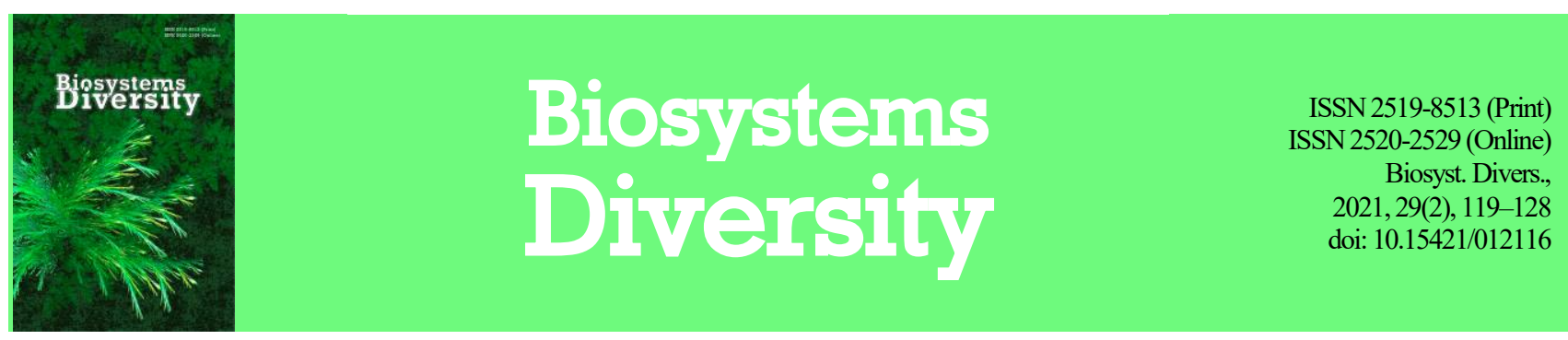

\title{
Phytoplankton succession in the anthropogenic and climate ecological transformation of freshwater ecosystems
}

\author{
Y. S. Shelyuk, L. Y. Astahova \\ Zhytomyr Ivan Franko State University, Zhytomyr, Ukraine
}

Article info

Received 25.04.2021

Received in revised form 27.05.2021

Accepted 28.05.2021

Zhytomyr Ivan Franko State University, Velyka Berdychivska st. 40, Zhytomyr, 10008, Ukraine. Tel.: +38-041-243-14-17. E-mail:Shelyuk_Yulya@ukr.net

Shelyuk, Y. S., \& Astahova, L. Y. (2021). Phytoplankton succession in the anthropogenic and climate ecological transformation of freshwater ecosystems. Biosystems Diversity, 29(2), 119-128. doi:10.15421/012116

The study is focused on the influence of mechanisms of anthropogenic activity and climate changes of different types and levels on the autotrophic link of freshwater ecosystems. The studies of the river, lake, water reservoir and quarry phytoplankton in the territory of the Ukrainian Polissia were carried out during 2005-2019 according to the standard methods. At the same time, we determined water hydrophysical and hydrochemical characteristics. Exactly 812 algal species represented by 877 infraspecific taxa were identified, including 75 new ones for the Ukrainian Polissia, with a significant share of thermophiles and halophiles. The dominance of Chlorophyta, Bacillariophyta, Euglenozoa and Cyanobacteria was observed in all types of water bodies. With the increase in the nutrient content in the composition of dominant complexes of river ecosystems, the role of centric diatoms Cyclotella meneghiniana, C. stelligera, Stephanodiscus hantzschii increased. The vegetation intensity of Aphanizomenon flosaquae increased in the water courses with partially regulated flow, while vegetation of Chrysococcus rufescens, Pseudokephyrion pillidium, Kephyrion ovum intensified in rivers with increased colour of water. Water reservoirs are dominated by representatives of Bacillariophyta, Cyanobacteria, Euglenozoa, Miozoa, mostly by Aphanizomenon flos-aquae and Peridinium cinctum. The lowest number of dominant species was identified in the lakes, and belonged to the genera Trachelomonas, Peridinium, Chlamydomonas, Crucigeniella, Cyclotella, Aulacoseira. The dominant species in quarries were Cyclotella meneghiniana, Chlamydomonas monadina, Ch. globosa, Coelastrum microporum, Gomphosphaeria aponina, Trachelomonas volvocina and Microcystis aeruginosa. The obtained data can be used to predict scenarios of changes in the autotrophic link under the influence of natural and anthropogenic factors, to develop methods for monitoring and managing ecosystems at different levels of anthropogenic transformation necessary to ensure an appropriate level of their functions and ecological services.

Keywords: algae; diversity; freshwater ecosystems; climate change; biological invasion.

\section{Introduction}

The leading role in the functioning of freshwater ecosystems belongs to phytoplankton, which converts inorganic compounds into high-energy organic matter in water bodies of various types in the process of photosynthesis. Photosynthetic products are involved in trophic chains and the circulation of matter and energy. Accordingly, phytoplankton is the main biotic factor that forms the structural and functional features of hydrobiota at different levels of its organization and determines the mechanisms of aquatic ecosystems functioning (Odum, 1986). The structural and functional characteristics of phytoplankton of aquatic ecosystems are a sensitive indicator of habitat, reflecting the features of natural development and the degree of anthropogenic load (Shcherbak \& Semenyuk, 2009; Barinova et al., 2015; Deng et al., 2016). Identification of the patterns in structural and functional organizations of ecosystems provides a theoretical basis for assessing their condition, the influence of natural and anthropogenic factors, predicting changes, rational use of water resources (Afanasyev, 2002; Mineeva et al., 2012). Algofloristic studies have covered many regions of the world since the middle of the last century (Barinova et al., 2011; Omar \& Makhlough, 2014; Xuehual et al., 2019). However, the data accumulated in the scientific literature are mainly related to the certain types of aquatic ecosystems (Santana et al., 2017; Rodrigues et al., 2018; Cupertino et al., 2019). The study of formation and functioning of the patterns of the main autotrophic link in typologically different water bodies under the influence of natural and anthropogenic factors using the basin principle on the example of the Ukrainian Polissia can contribute to the further development of ideas about changes in aquatic communities (Shelyuk \& Shcherbak, 2018). In addition, the relevance of such studies is due to the fact that Polissia is one of the most important natural reservoirs of fresh water in Ukraine, which is used by almost half of the entire population of the country. Some of the regional watercourses are transboundary, which gives rise to the need to assess their ecological state. Moreover, there are objects of the nature reserve fund in the basins of the main Polissia rivers - the Pripyat and Teteriv. Man-made water bodies constructed in the locations of quarries for sand, granite, ilmenite extraction are an integral element of the landscapes of the Ukrainian Polissia. The study of these underinvestigated water bodies is relevant, since it allows us to determine the patterns of development of ecosystems of a new type with intensively occurring successions of the autotrophic link.

The catchment basins of Polissia are influenced by an intense anthropogenic load, since they are an important component of the diversified economy of Ukraine with a significant concentration of industrial and agricultural production. Extensive soil reclamation in the region, regulation of Polissia rivers, anthropogenic pollution, including the accident at the Chernobyl nuclear power plant, have caused significant environmental consequences in the last century. In the recent decades, the impact of climate change on aquatic organisms has increased (Klimaszyk \& Gokdyn, 2020). According to the data from experts, in recent years, it is the territory of Polissia that is undergoing the most noticeable temperature rise, even compared with the southern regions (Tuz, 2012), which may lead to the disappearance of this zone with time. The objective of this research was comparing the features of the structure and functioning of plankton algal communities of different aquatic ecosystem types: rivers, lakes, water reservoirs and quarries of the Ukrainian Polissia such as the rivers Prypiat and Teteriv. The study resulted in the identification of the main regularities in the development of phytoplankton of aquatic ecosystems, which are different in the conditions of hydrobionts' existence and the level of anthropogenic load. 


\section{Material and methods}

The data for the study was the samples taken in different types of water bodies in the basins of the main rivers of the Ukrainian Polissia, the Pripyat and the Teterev during 2005-2019. The research covered such

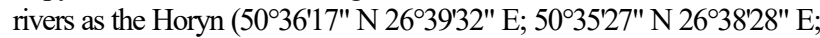
$50^{\circ} 07^{\prime} 19^{\prime \prime} \mathrm{N} 26^{\circ} 48^{\prime} 55^{\prime \prime} \mathrm{E} ; 50^{\circ} 08^{\prime} 15^{\prime \prime} \mathrm{N} 26^{\circ} 49^{\prime} 07^{\prime \prime} \mathrm{E} ; 50^{\circ} 06^{\prime} 00^{\prime \prime} \mathrm{N}$ $26^{\circ} 47^{\prime 2} 26^{\prime \prime}$ E), the Sluch $\left(50^{\circ} 01^{\prime} 42^{\prime \prime}\right.$ N 27 $41^{\prime 2} 27^{\prime \prime}$ E; $50^{\circ} 36^{\prime} 04^{\prime \prime} \mathrm{N}$

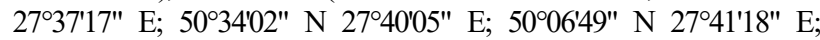
$50^{\circ} 06^{\prime} 11^{\prime \prime} \mathrm{N} 27^{\circ} 41^{\prime 2} 22^{\prime \prime} \mathrm{E} ; 50^{\circ} 05^{\prime} 28^{\prime \prime} \mathrm{N} 27^{\circ} 40^{\prime} 59^{\prime \prime}$ E), the Uzh (50 $57^{\circ} 01^{\prime \prime}$

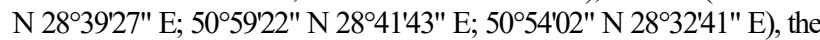

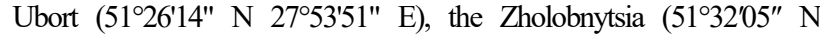
$\left.28^{\circ} 06^{\prime} 20^{\prime \prime} \mathrm{E}\right)$, the Korchyk $\left(50^{\circ} 37^{\prime} 19^{\prime \prime} \mathrm{N} 27^{\circ} 09^{\prime} 41^{\prime \prime} \mathrm{E}\right)$, the Vilia

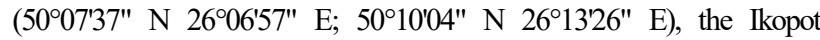
$\left(49^{\circ} 45^{\prime} 37^{\prime \prime} \mathrm{N} 27^{\circ} 12^{\prime} 30^{\prime \prime} \mathrm{E}\right)$, the Polkva (49 $58^{\prime} 59^{\prime \prime} \mathrm{N} 26^{\circ} 24^{\prime} 35^{\prime \prime} \mathrm{E}$;

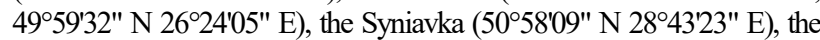

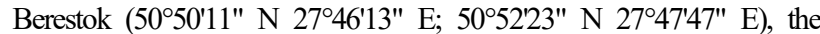

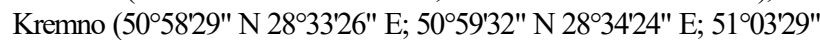

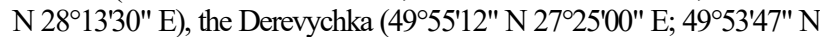
$27^{\circ} 23^{\prime} 02^{\prime \prime}$ E), the Hnylopiat (4953'14" N 2834'48" E; 49 $566^{\circ} 21^{\prime \prime} \mathrm{N}$ $28^{\circ} 33^{\prime} 01^{\prime \prime}$ E; $50^{\circ} 0638^{\prime \prime}$ N $28^{\circ} 31^{\prime} 09^{\prime \prime}$ E), the Lisova Kamianka (50¹ $18^{\prime} 03^{\prime \prime}$ N $28^{\circ} 366^{\prime \prime}$ E), the Putiatynka $\left(50^{\circ} 15^{\prime} 00^{\prime \prime}\right.$ N $28^{\circ} 41^{\prime} 53^{\prime \prime}$ E), the Lisna

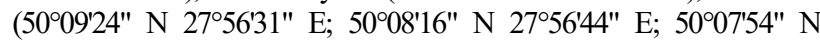
$\left.27^{\circ} 57^{\prime} 05^{\prime \prime} \mathrm{E}\right)$, the Kroshenka (50¹7'49" N $28^{\circ} 37^{\prime} 39^{\prime \prime}$ E), the Kodnianka $\left(50^{\circ} 06^{\prime} 58^{\prime \prime} \mathrm{N} 28^{\circ} 41^{\prime} 35^{\prime \prime} \mathrm{E}\right)$, the Bobrivka (50 $\left.13{ }^{\prime} 50^{\prime \prime} \mathrm{N} 28^{\circ} 23^{\prime} 28^{\prime \prime} \mathrm{E}\right)$, the

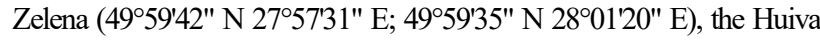

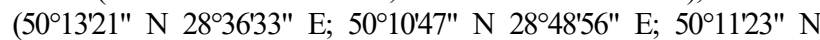
$28^{\circ} 41^{\prime} 35^{\prime \prime}$ E); karst lakes Luko (5136'29" N 2601'11" E), Voronky

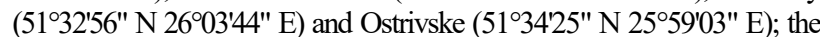
lake of postglacial origin Didove $\left(51^{\circ} 23^{\prime} 21^{\prime \prime} \mathrm{N} 28^{\circ} 01^{\prime} 22^{\prime \prime} \mathrm{E}\right)$, the part of the cognominal hydrological reserve of national importance in Ukraine and the swampy lake Horokhivka $\left(51^{\circ} 20^{\prime} 42^{\prime \prime}\right.$ N $28^{\circ} 51^{\prime} 15^{\prime \prime}$ E); water reservoirs: Denyshyvske Water Reservoir $\left(50^{\circ} 12^{\prime 2} 9^{\prime \prime}\right.$ N $28^{\circ} 24^{\prime} 32^{\prime \prime}$ E), Zhytomyrske Water Reservoir (50 $14^{\prime} 05^{\prime \prime}$ N $28^{\circ} 36^{\prime} 38^{\prime \prime}$ E), Berdychivske Water Reservoir (4953'20" N 28 $34^{\prime} 41^{\prime \prime}$ E), Novograd-Volynske Water Reservoir (50³5'53" N 2737'28" E), Myropilske Water Reservoir (50 06'26" N 27 $\left.411^{\prime} 25^{\prime \prime} \mathrm{E}\right)$; as well as flooded quarries for mining: granite - Bogunsky Quarry (50¹7'23" N 28 36'30" E), Kroshensky Quarry

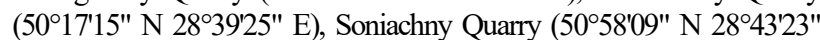
E), Kirpichny Quarry (50 56'24" N 28 39'51" E) and Morozovsky Quarry $\left(50^{\circ} 37^{\prime} 22^{\prime \prime} \mathrm{N} 27^{\circ} 0721^{\prime \prime} \mathrm{E}\right)$; sand quarries - Seletsky Quarry $\left(50^{\circ} 13^{\prime} 42^{\prime \prime}\right.$

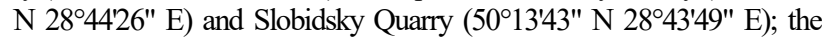
quarry for the extraction of ilmenite ores of Irshansk mining and processing plant $\left(50^{\circ} 47^{\prime} 02^{\prime \prime} \mathrm{N} 28^{\circ} 35^{\prime} 25^{\prime \prime} \mathrm{E}\right)$.

The samples were taken monthly during 3 growing seasons (March November) and processed according to the standard methods (Romanenko, 2006). In total, 2020 algological samples were taken using the MIKMED microscope-1 33.23.233TO (LOMO, Russia, 2004). The taxonomic nomenclature of algae is given according to the international electronic catalog AlgaeBase (Guiry \& Guiry, 2020, www.algaebase.org). Phytoplankton biomass was determined by the volumetric calculation method (Romanenko, 2006). The species with biomass reaching or exceeding $10 \%$ of the phytoplankton biomass in the sample were considered to be dominant. Saprobiological assessment of water quality is based on the Pantle-Buck method modified by Sladeček (1986). Informational diversity (by phytoplankton biomass) was calculated using the Shannon index (Odum, 1986). The assessment of the trophic status of water is given according to (Romanenko, 2006). Simultaneously with the collection of algological samples, we measured water temperature using a TB-3-M1 mercury thermometer (Steklopribor, Ukraine, 2002); transparency - according to the standard Secchi disk; colour - using a dichromate cobalt scale; the content of oxygen dissolved in water - by the Winkler method; $\mathrm{pH}-\mathrm{pH}$ meter pH-150M (Measuring equipment, Ukraine, 2005); phosphorus phosphates - by spectrometric method; nitrate nitrogen - by the calorimetric method, as well as ammonium and nitrite nitrogen with a KFK-3 photocolorimeter (ZOMP, Russia, 2001). Hydrochemical and hydrophysical analyses were carried out seasonally during 2010-2019 in all the types of water bodies once a season. The data on the content of silicium in Denyshyvske Water Reservoir were kindly provided by the employees of the
Department of Freshwater Hydrochemistry of the Institute of Hydrobiology of National Academy of Sciences of Ukraine T. P. Zhezherei, P. M. Linnik, V.A. Zhezherei, to whom the authors are extremely grateful (Linnik et al., 2016). The indication of algal species in relation to the temperature factor was carried out according to (Barinova, 2011).

The peculiarities of the Pripyat and Teterev drainage basins determine the low salinity typical for freshwaters and moderate waterlogging of the territory. The obtained results confirm that the colour of the water mainly corresponds to the mesohumous type and increased in the following order: quarries $\rightarrow$ rivers $\rightarrow$ water reservoirs $\rightarrow$ lakes (Table 1 ). The highest average value of this indicator was noted in Lake Didovoe, which is a part of the hydrological reserve of the same name with national importance status. Due to the significant anthropogenic component in the Pripyat and Teterev basins, a fairly high content of biogenic elements was noted in the water bodies of all types. Averaging the obtained data by types of water bodies showed that the highest content of total nitrogen was in the quarries and decreased in the following order: quarries $\rightarrow$ lakes $\rightarrow$ water reservoirs $\rightarrow$ rivers. The phosphorus phosphate content was the lowest in lakes and increased in the following order: lakes $\rightarrow$ rivers $\rightarrow$ water reservoirs $\rightarrow$ quarries.

\section{Table 1}

Main abiotic characteristics of water bodies of different types in the Pripyat and Teterev basins (based on the results of seasonal studies in 2010-2019)

\begin{tabular}{|c|c|c|c|c|}
\hline \multirow[b]{2}{*}{ Indicators } & \multicolumn{4}{|c|}{ Water Bodies } \\
\hline & rivers & lakes & $\begin{array}{l}\text { water } \\
\text { reservoirs }\end{array}$ & quarries \\
\hline Transparency, $m$ & $0.77 \pm 0.03$ & $0.62 \pm 0.05$ & $1.09 \pm 0.02$ & $1.21 \pm 0.02$ \\
\hline Coluor, $^{\circ}$ & $36.21 \pm 1.60$ & $47.74 \pm 4.52$ & $42.70 \pm 0.85$ & $23.33=$ \\
\hline$p H$ & $7.34 \pm 0.09$ & $7.22 \pm 0.09$ & $7.84 \pm 0.18$ & $6.90 \pm 0.06$ \\
\hline $\begin{array}{l}\text { Dissolved oxygen content, } \\
\mathrm{mg} \mathrm{O}_{2} /\left(\mathrm{dm}^{3} \cdot \text { day }\right)\end{array}$ & $9.93 \pm 1.64$ & $8.68 \pm 0.61$ & $11.2 \pm 0.67$ & $7.82 \pm 0.11$ \\
\hline Surface water temperature, ${ }^{\circ} \mathrm{C}$ & $15.68 \pm 0.84$ & $17.30 \pm 1.10$ & $17.50 \pm 0.72$ & $17.42 \pm 0.32$ \\
\hline $\begin{array}{l}\text { Total nitrogen content, } \\
\mathrm{mg} N / \mathrm{dm}^{3}\end{array}$ & $=0.04$ & $2.05 \pm 0.42$ & $1.45 \pm 0.14$ & $3.21 \pm 0.22$ \\
\hline $\begin{array}{l}\text { Phosphorus phosphate } \\
\text { content, } \mathrm{mg} P / \mathrm{dm}^{3}\end{array}$ & $\begin{array}{c}0.051 \pm \\
0.003\end{array}$ & $\begin{array}{c}0.020 \pm \\
0.001\end{array}$ & $\begin{array}{c}0.071 \pm \\
0.002\end{array}$ & $\begin{array}{c}0.083 \pm \\
0.003\end{array}$ \\
\hline
\end{tabular}

According to the average temperature of water surface layer for the growing season, water bodies of the lentic type differed slightly; a decrease in this indicator was observed in the rivers, primarily due to wind mixing of water masses.

Having morphometric specifics, the studied reservoirs and water courses differed in hydro-optical parameters. The highest transparency of water masses was observed in quarries and water reservoirs with deep water and low content of suspended solids. In shallower water bodies, such as lakes and especially rivers, the role of suspended matter increases due to flow and wind mixing, therefore decreasing transparency. A decrease in transparency was observed in the following order: quarries $\rightarrow$ water reservoirs $\rightarrow$ rivers $\rightarrow$ lakes. Granite quarries were characterized by higher transparency of water in comparison with sand ones, and the least transparency was noted in the ilmenite quarry of Irshansk Mining and Processing Plant, which is probably due to the morphometric features of these water reservoirs. The lowest average $\mathrm{pH}$ values were recorded in the quarries, they increased in the following order: quarries $\rightarrow$ lakes $\rightarrow$ rivers $\rightarrow$ water reservoirs.

The data were statistically analyzed using variational methods in Statistica 6.0 (StatSoft, USA, 2006). The coefficient matrices of species similarity were processed by cluster analysis with the development of dendrograms using the Past v3.17 package (Hammer \& Harper, USA, 2001) according to the Sorensen index for similarity in species composition (Sorensen, 1948). To obtain general characteristics of the obtained field data, their mean values were calculated and expressed as the mean value \pm standard error $(\mathrm{x} \pm \mathrm{SE})$.

\section{Results}

During the period of the research, 812 species of algae were identified in water bodies and watercourses of the Pripyat and Teterev river basins, 
represented by 877 infraspecific taxa with the species type nomenclature including, belonging to 261 genera, 99 families, 43 orders, 15 classes and 8 divisions, according to which the identified species and intraspecific taxa were distributed as follows: Cyanobacteria - 98 species (100 intraspecific taxa), Euglenozoa - 131 (169), Chromophyta - 51 (53), Bacillariophyta 220 (233), Miozoa - 37 (38), Cryptophyta - 5 (5), Chlorophyta - 235 (243) and Charophyta 35 (36).

The phytoplankton of the studied water bodies differed in species richness. There were 54 to 174 species of algae in the rivers, 28 to 83 in the lakes, 57 to 184 in the reservoirs and 30 to 172 in the water bodies created on the sites of flooded quarries. The maximum average number of species and intraspecific taxa was identified in the water reservoirs (118.8 \pm 2.82 ). The richest in species composition was the phytoplankton of the Zhytomyrske Water Reservoir (174 species, represented by 184 intraspecific taxa), which receives the water of the tributaries - the Hnylipiat and Huiva rivers. The share of representatives of the Cyanobacteria and Miozoa divisions increases with increase in the area and volume of water reservoirs, whereas that of Euglenozoa grows with decrease in the size of water bodies. The second position in terms of the average number of species in phytoplankton belongs to the rivers $(106.8 \pm 5.29)$, the third the aquatic ecosystems developed on the sites of flooded quarries (98.7 \pm 3.00). The smallest average number of species was represented by the lake plankton $(58.4 \pm 2.44)$. In terms of the number of taxa with a rank lower than the genus, green algae and diatoms dominated in the general list of species in the water bodies of all types. Blue-green algae were the third regarding the species richness in the largest reservoirs - Zhytomyrske Water Reservoir and Denyshivske Water Reservoir, Voronkivske, Ostrivske and Didove lakes, also Bohunsky, Soniachny, Sokolovsky, Kroshensky and Irshanskiy ilmenite quarries. Euglenozoa hold the third position in the smaller reservoirs - Miropilske Water Reservoir and Novograd-Volynske Water Reservoir and most rivers.

Cluster analysis revealed that the phytoplankton of rivers and reservoirs had the greatest species similarity. This is explained by the fact that the biological regime of water reservoirs depends on the water flow of the rivers they are created on, as well as a number of abiotic factors that are directly or indirectly related to the regulation of rivers. Lakes are included in a separate cluster, which indicates the specific habitat of limnoplankton (Fig. 1).

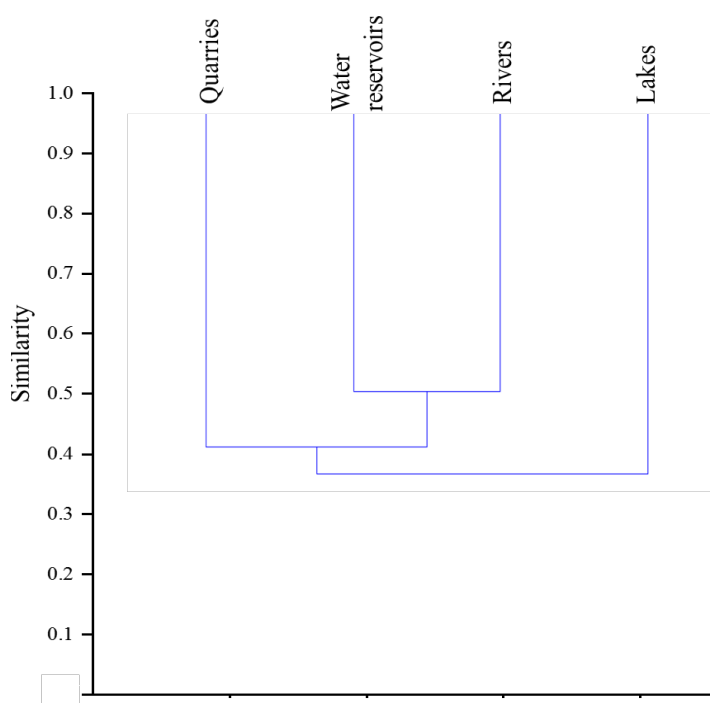

Fig. 1. Dendrogram of phytoplankton species similarity of different types of water bodies in Polissia according to the results of studies in 2005-2019

The comparison of the phytoplankton algal composition of the studied rivers and reservoirs indicates the distinctive characters of these aquatic ecosystems $\left(\mathrm{K}_{\mathrm{S}}=0.09-0.91\right)$. A strong similarity in the algal species composition was typical to the rivers Kroshenka and Gnilopyat $\left(\mathrm{K}_{\mathrm{S}}=\right.$ 0.91 ), which is provided not only by similar geomorphological and hydrochemical conditions, but, probably, by the influence of the anthropogenic load of Zhytomyr. A significant similarity was also noted between the species composition of Zhytomyrske Water Reservoir and Denyshivske Water Reservoir $\left(K_{S}=0.73\right)$. The comparison of the phytoplank- ton species composition in lakes showed that significant species similarity is typical of the karst lakes Luko, Voronki and Ostrivskoe $\left(\mathrm{K}_{\mathrm{S}}=0.49\right.$ 0.52 ). The phytoplankton of the lakes Didove and Gorokhivka were quite peculiar $\left(K_{S}=0.28-0.31\right)$. Among the water reservoirs of anthropogenic origin, the greatest floristic similarity was noted for the phytoplankton of granite quarries in Zhytomyr - Soniachny and Bogunsky $\left(\mathrm{K}_{\mathrm{S}}=0.89\right)$, as well as sand ones - Seletsky and Slobidsky $\left(\mathrm{K}_{\mathrm{S}}=0.77\right)$. The Sokolovsky and Irshansky quarries had the greatest uniqueness $\left(K_{S}=0.29\right)$.

With an increase of the total iron content (up to $0.61-2.40 \mathrm{mg} / \mathrm{dm}^{3}$ ), an increase in the share of diatoms in the total phytoplankton composition was observed in rivers $(\mathrm{r}=0.38, \mathrm{P}=0.000001, \mathrm{n}=57)$.

A strong negative correlation was observed between water colour and the number of taxa below the genus rank in algological samples taken in rivers, lakes and water reservoirs (consequently $\mathrm{r}=-0.79, \mathrm{P}=0.000127$, $\mathrm{n}=76 ; \mathrm{r}=-0.70, \mathrm{P}=0.000001, \mathrm{n}=30 ; \mathrm{r}=-0.71, \mathrm{P}=0.021335, \mathrm{n}=36$ ). In quarries it was moderate $(\mathrm{r}=-0.45, \mathrm{P}=0.011545, \mathrm{n}=38$, Fig. 2$)$.

The generic coefficients in the rivers reached 1.48-2.67, in water reservoirs - 1.36-2.04, in lakes - 1.27-1.83, in quarries - 1.16-1.89. The influence of total nitrogen content on structure of the communities in the water reservoirs and quarries was stronger than in the natural waters the rivers and lakes; the correlation coefficients between the total nitrogen content and generic coefficients confirm that (in quarries $\mathrm{r}=-0.74, \mathrm{P}=$ $0.000001, \mathrm{n}=46$; in reservoirs $\mathrm{r}=-0.71, \mathrm{P}=0.021335, \mathrm{n}=32$; in lakes $\mathrm{r}=-0.39, \mathrm{P}=0.000288, \mathrm{n}=34$; in rivers $\mathrm{r}=-0.42, \mathrm{P}=0.00001, \mathrm{n}=63$ ) (Fig. 3). The average values of the generic coefficient decreased in the following order: rivers $(1.90) \rightarrow$ water reservoirs $(1.74) \rightarrow$ lakes $(1.53) \rightarrow$ quarries (1.43). In the rivers, lakes and water reservoirs, the increase of the total nitrogen content (respectively, $\mathrm{r}=0.52, \mathrm{P}=0.000001, \mathrm{n}=63 ; \mathrm{r}=$ $0.54, \mathrm{P}=0.000001, \mathrm{n}=34 ; \mathrm{r}=0.67, \mathrm{P}=0.000001, \mathrm{n}=36$ ) causes an increase in the diatom coefficient (the ratio of the number of centric diatoms species to the number of penate algae), indicating increase in the role of highly productive small-celled centric diatoms. The relationship between the diatom coefficient and the total nitrogen content in quarries was moderate $(r=0.31, P=0.00071, n=46$, Fig. 4$)$.

The highest average number of algal cells for the growing seasons was noted in the reservoirs $\left(9.29 \pm 1.45\right.$ million cells $\left./ \mathrm{dm}^{3}\right)$ and rivers $\left(5.58 \pm 0.98\right.$ million cells $\left./ \mathrm{dm}^{3}\right)$. This indicator was significantly lower in the quarries and lakes $\left(1.79 \pm 0.09\right.$ and $1.38 \pm 0.25$ million cells $/ \mathrm{dm}^{3}$, respectively). In most of the water bodies, regardless of their type, the seasonal dynamics of the number of algal cells was determined by bluegreen algae. However, green algae grew most massively in the rivers Korchyk, Berestok, Kodnianka, Kroshenka and Horyn (in the rivers Korchyk and Berestok throughout all seasons; in the Horyn river - in summer and autumn; in the Kodnianka river - in spring and summer; in the Kroshenka river - only in autumn; in the Ubort river - in spring). Diatoms prevailed in the number of algal cells in Lake Ostrivske throughout all seasons, green ones - in Lake Gorokhivka. Diatoms prevailed in the number of algal cells throughout all seasons in Lake Ostrivske and green algae in Lake Gorokhivka. During the growing seasons, the average phytoplankton biomass decreased in the following order: water reservoirs $\left(2.88 \pm 0.37 \mathrm{mg} / \mathrm{dm}^{3}\right) \rightarrow$ rivers $\left(2.30 \pm 0.29 \mathrm{mg} / \mathrm{dm}^{3}\right) \rightarrow$ quarries $(1.95 \pm$ $\left.0.15 \mathrm{mg} / \mathrm{dm}^{3}\right) \rightarrow$ lakes $\left(1.36 \pm 0.15 \mathrm{mg} / \mathrm{dm}^{3}\right)$. The higher values of the biomass of algal communities in the water reservoirs and rivers are likely due to their biotopic heterogeneity with a large availability of resources. The decrease of biomass in particular rivers (the average phytoplankton biomass was $0.298 \pm 0.02 \mathrm{mg} / \mathrm{dm}^{3}$ in the Berestok River and $0.594 \pm$ $0.07 \mathrm{mg} / \mathrm{dm}^{3}$ in the Kamianka Lisova River) is explained by the anthropogenic load on their aquatic ecosystems (including wastewater). Aquatic ecosystems are characterized by seasonal variability of phytoplankton biomass with the main role of Chlorophyta, Cyanobacteria, Euglenozoa, and Bacillariophyta in plankton communities. Blue-green algae prevail in water reservoirs. A shift in biomass maxima from spring - summer to late summer - early autumn caused by changes in phytoplankton composition was noted in the aquatic ecosystems with a high trophic status. Also, the reason for this may be the fact that in the autumn period, the average water temperature has increased over the past few decades, and correspondingly, the growing season of algae has extended. Irrespective of the trophic status of waters, several maxima of biomass in the quarries were observed during the growing season (mostly in spring, summer and autumn). 

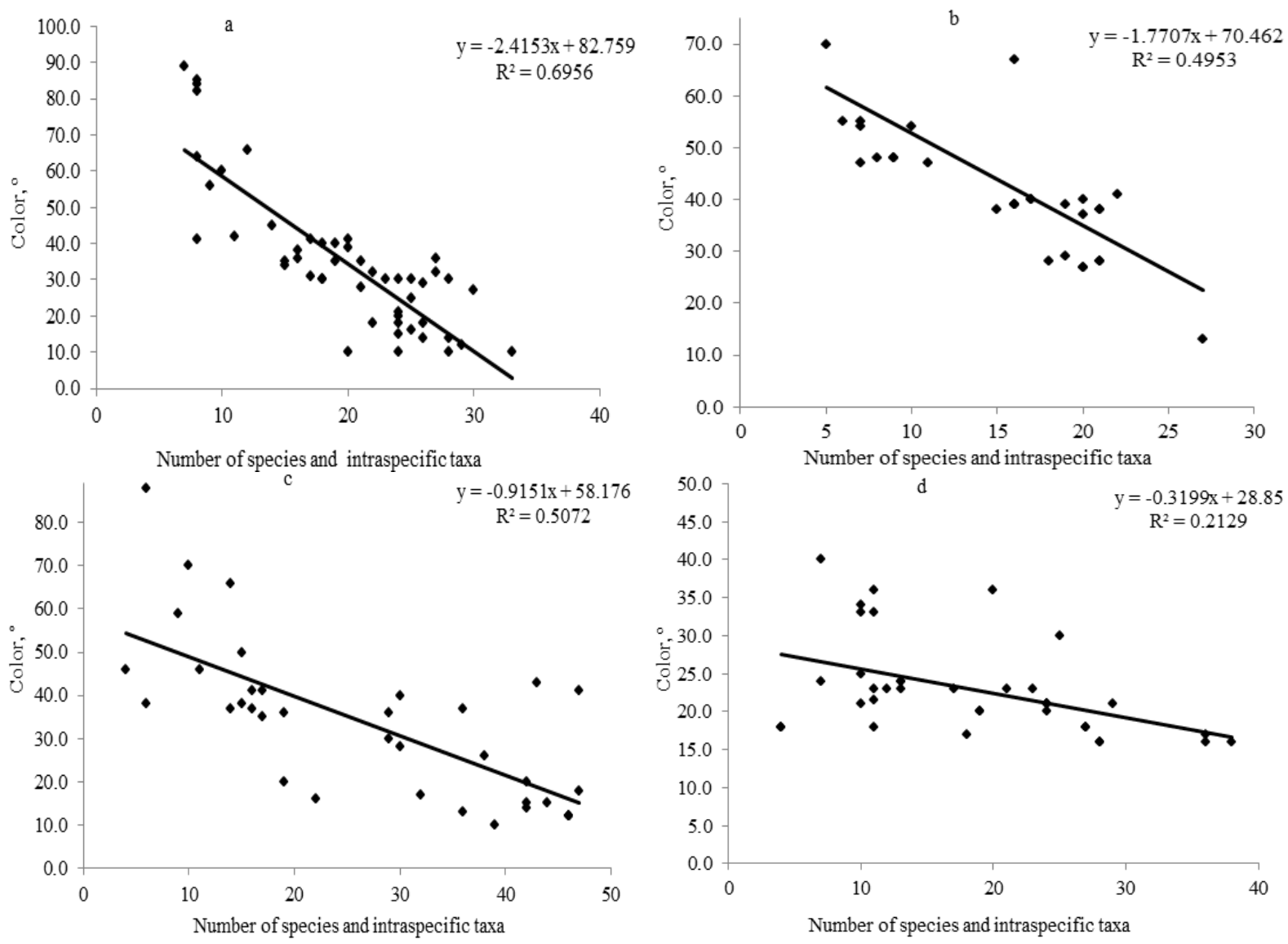

Fig. 2. The relationship between water color and the number of specific and infraspecific taxa of algae in different types of water bodies of the Ukrainian Polissia according to the results of studies in 2015 - 2019: $a$-rivers, $b$-lakes, $c$-water reservoirs, $d$-quarries
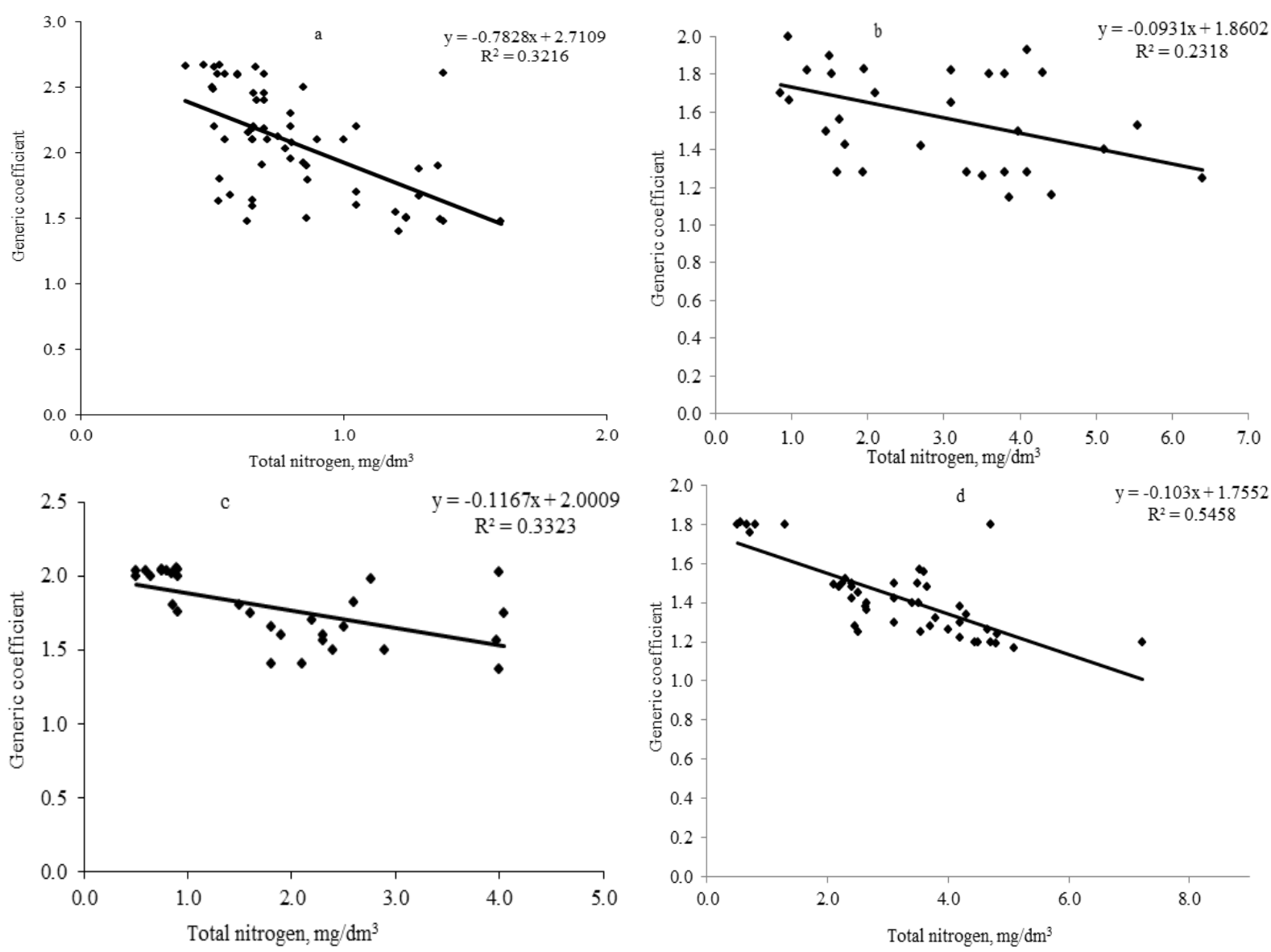

Fig. 3. The relationship between the content of total nitrogen and the generic coefficient of phytoplankton in different types of water bodies of the Ukrainian Polissia according to the results of studies in 2015-2019: $a$-rivers, $b$-lakes, $c$-water reservoirs, $d$ - quarries 
Diatoms determine the migration of silicon in water: using the Denyshivske Water Reservoir as an example, it is shown that the spring growth of diatoms biomass promotes the extraction of dissolved silicon from water, but at the same time, there was recorded an increase in the content of its suspended form. In winter, when the intensity of algae vegetation decreases, the consumption of the dissolved form of $\mathrm{Si}$ is reduced to minimum, and as a result, the content of the suspended form of silicon decreases as well. The absorption of dissolved silicon by diatom plankton from water is not just absorption, it is based on the transformation process -
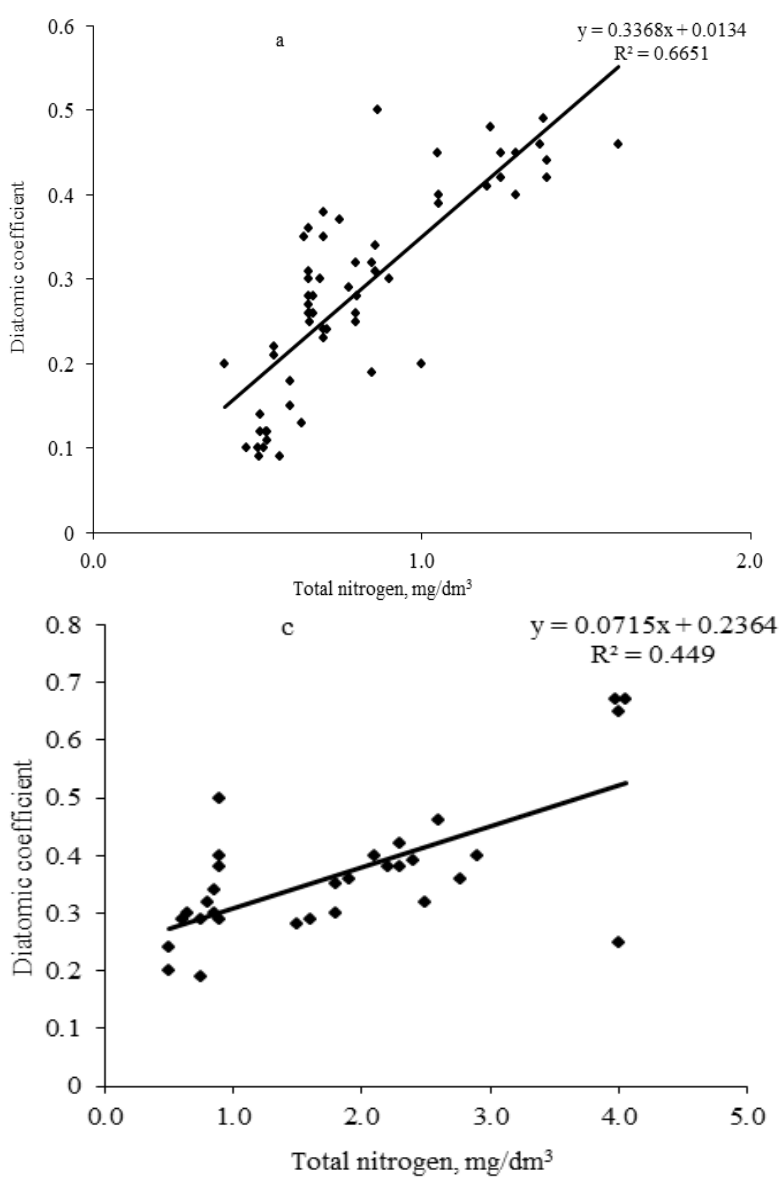

the transformation of coexisting forms of silicon - dissolved into suspended silicon with the participation of diatoms. The comparison of the concentration of the suspended form of silicon and the biomass of diatoms in the water of the Denyshivske Water Reservoir, as well as their accumulation throughout the year, showed that with an increase in the diatoms biomass, the silicon content in the suspension also increases. A positive correlation was determined between these indicative values $(\mathrm{r}=0.73$ at $\mathrm{P}=$ 0.000068 , and 0.63 at $\mathrm{P}=0.0001, \mathrm{n}=16$, respectively, for the surface and bottom horizons of the reservoir).

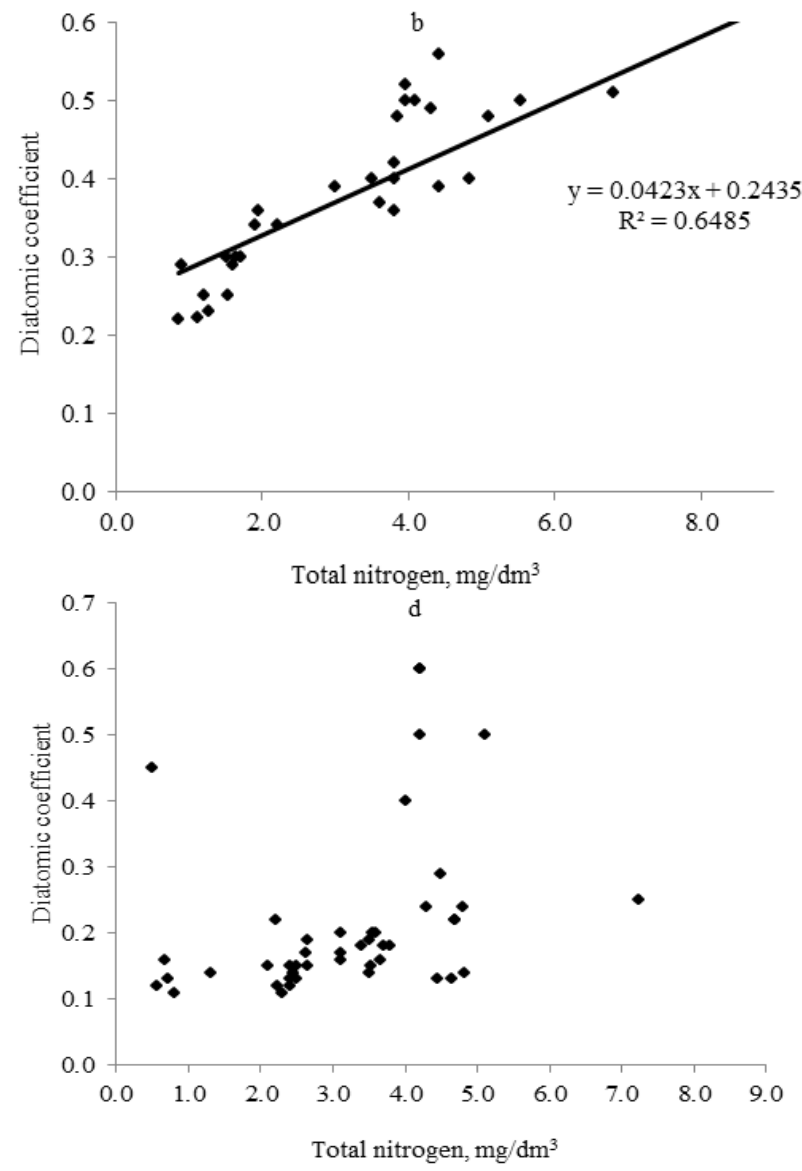

Fig. 4. The relationship between the content of total nitrogen and the diatom coefficient of phytoplankton in different types of water bodies of Polissia according to the results of studies in 2015-2019: $a$-rivers, $b$-lakes, $c$-water reservoirs, $d$-quarries

The feedback between the biomass and total nitrogen concentration was revealed in the rivers $(\mathrm{r}=-0.57, \mathrm{P}=0.000001, \mathrm{n}=63)$, reservoirs $(\mathrm{r}=$ $-0.61, \mathrm{P}=0.014259, \mathrm{n}=36)$ and lakes $(\mathrm{r}=-0.39, \mathrm{P}=0.00003, \mathrm{n}=34)$ and it is the result of its active absorption by algal cells; in water bodies formed at the sites of flooded quarries, the relationship is direct $(r=0.43$, $\mathrm{P}=0.000001, \mathrm{n}=46$, Fig. 5).

In comparison with other types of aquatic ecosystems, a more noticeable impact of phosphorus phosphates on phytoplankton biomass was noted in the reservoirs $(\mathrm{r}=0.46, \mathrm{P}=0.000522, \mathrm{n}=36)$.

The analysis of the phytoplankton informational diversity according to the Shannon diversity index $(\mathrm{H})$ showed that the highest values are found in river ecosystems. This indicator decreased in the following order: rivers $(\mathrm{H}=1.89 \pm 0.02 \mathrm{bit} / \mathrm{mg}) \rightarrow$ water reservoirs $(\mathrm{H}=1.76 \pm 0.03 \mathrm{bit} / \mathrm{mg}) \rightarrow$ lakes $(\mathrm{H}=1.64 \pm 0.05 \mathrm{bit} / \mathrm{mg}) \rightarrow$ quarries $(\mathrm{H}=1.62 \pm 0.10 \mathrm{bit} / \mathrm{mg})$. Increase in the nutrient content caused decrease in phytoplankton informational diversity in all types of aquatic ecosystems. Thus, a negative correlation was observed between the total nitrogen content and the Shannon diversity index in rivers $(\mathrm{r}=-0.62, \mathrm{P}=0.000001, \mathrm{n}=63)$, quarries $(\mathrm{r}=$ $-0.44, \mathrm{P}=0.000001, \mathrm{n}=46)$ and lakes $(\mathrm{r}=-0.46, \mathrm{P}=0.000240, \mathrm{n}=34)$ (Fig. 6).

Phosphorus of phosphates $(\mathrm{r}=-0.73, \mathrm{P}=0.039064, \mathrm{n}=54)$ was an abiotic parameter determining the value of information diversity in water reservoirs. The direct relationship between informational diversity and water temperature was determined only in the quarries $(r=0.54, \mathrm{P}=0.00024$, $\mathrm{n}=270$ ), changes in diversity were not limited by the temperature factor in other types of aquatic ecosystems.

The assessment of the levels of organic pollution in water bodies and watercourses of the Polissia by the average values of the saprobity indices showed that they mainly correspond to class II of water quality. Water quality deterioration was observed in particular aquatic ecosystems of all types, mostly in rivers and reservoirs with a high trophy level in autumn. The likely cause for this was the slowdown in self-purification processes, as well as secondary pollution with autochthonous organic matter. The average values of the saprobity index increased in the following order: lakes $(1.73 \pm 0.36) \rightarrow$ quarries $(1.74 \pm 0.20) \rightarrow$ water reservoirs $(1.77 \pm 0.06)$ $\rightarrow$ rivers $(1.85 \pm 0.06)$.

In the mesotrophic watercourses of the Polissia, the dominant phytoplankton complexes are composed of a significant number of species, among which the leading ones can be different species of genera Chlamydomonas Ehrenberg, Cyclotella (Kützing) Brébisson, Trachelomonas Ehrenberg, Euglena Ehrenberg, Peridinium Ehrenberg and Oscillatoria Vaucher ex Gomont. As the trophic level increases, the role of centric diatoms Cyclotella meneghiniana Kützing, C. Stelligera (Cleve \& Grunow) Van Heurck, Stephanodiscus hantzschii Grunow increases as well. The vegetation intensity of Aphanizomenon flos-aquae Ralfs ex Bornet \& Flahaul increased in the rivers with partially regulated flow (the rivers Hnylopiat, Huiva, Vilia). In rivers with increased colour (the rivers Ubort, Uzh), the dominant complex included representatives of the Ochrophyta 
division: Chrysococcus rufescens Klebs, Pseudokephyrion pillidium Schiller, Kephyrion ovum Pascher). In the water reservoirs, the dominant complex was mainly composed of different species of the genera Cyclotella, Stephanodiscus Ehrenberg, Aphanizomenon A. Morren ex É. Bornet \& C. Flahault, Oscillatoria, Anabaena Bory ex Bornet \& Flahault, Nitzschia Hassall, F. Schrank, Navicula Bory, Phacotus Perty, Acutodesmus (Hegewald) Tsarenko and Coelastrum Nägeli. In the lakes, the dominant phytoplankton complexes were represented by a relatively smaller number of species, which mostly belonged to the genera Crucigeniella Lem-
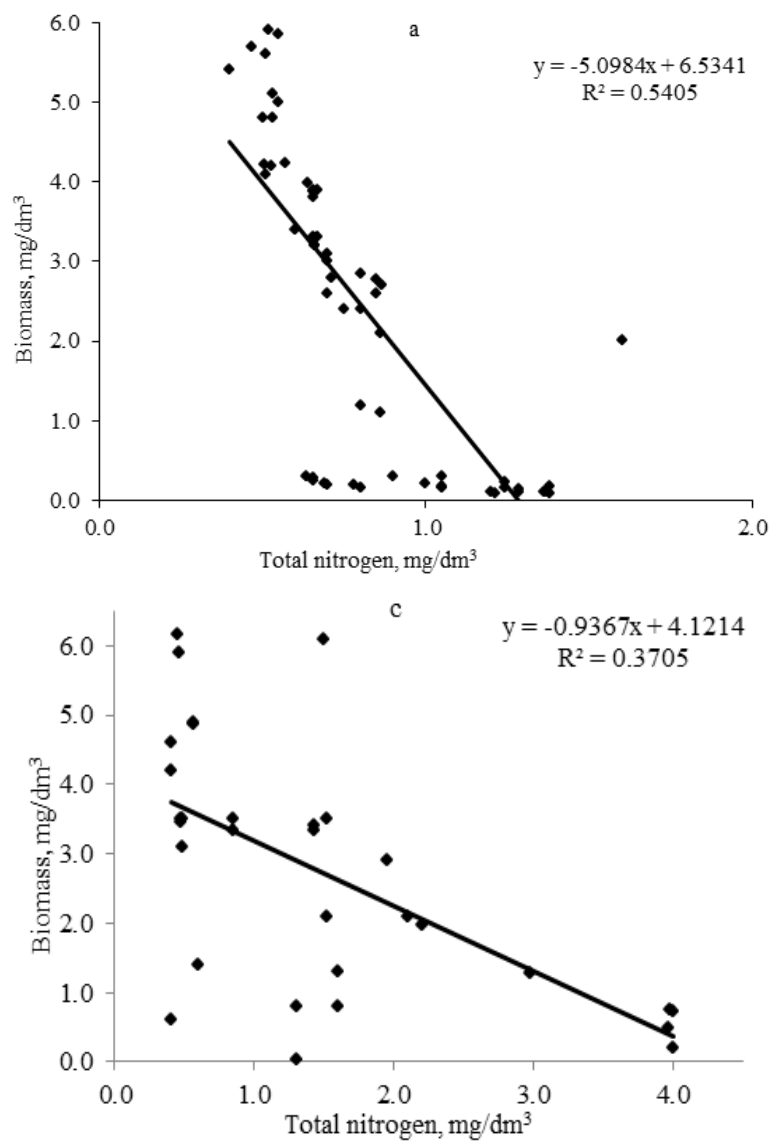

mermann, Cyclotella, Peridinium, Chlamydomonas, Aulacoseira Thwaites. The dominant quarry complexes were distinct by their individuality, as indicated by the absence of common dominant species in them and low coefficients of species similarity between the lists of such algal species $\left(K_{\mathrm{s}}=0.01-0.48\right)$. This indicates the uniqueness of the development of dominant complexes in man-made water bodies. In most of the quarries, the dominant species were Cyclotella meneghiniana, Chlamydomonas monadina (Ehrenberg) F. Stein, Ch. globosa J. W. Snow, Coelastrum microporum Nägeli, Microcystis aeruginosa (Kützing) Kützing.
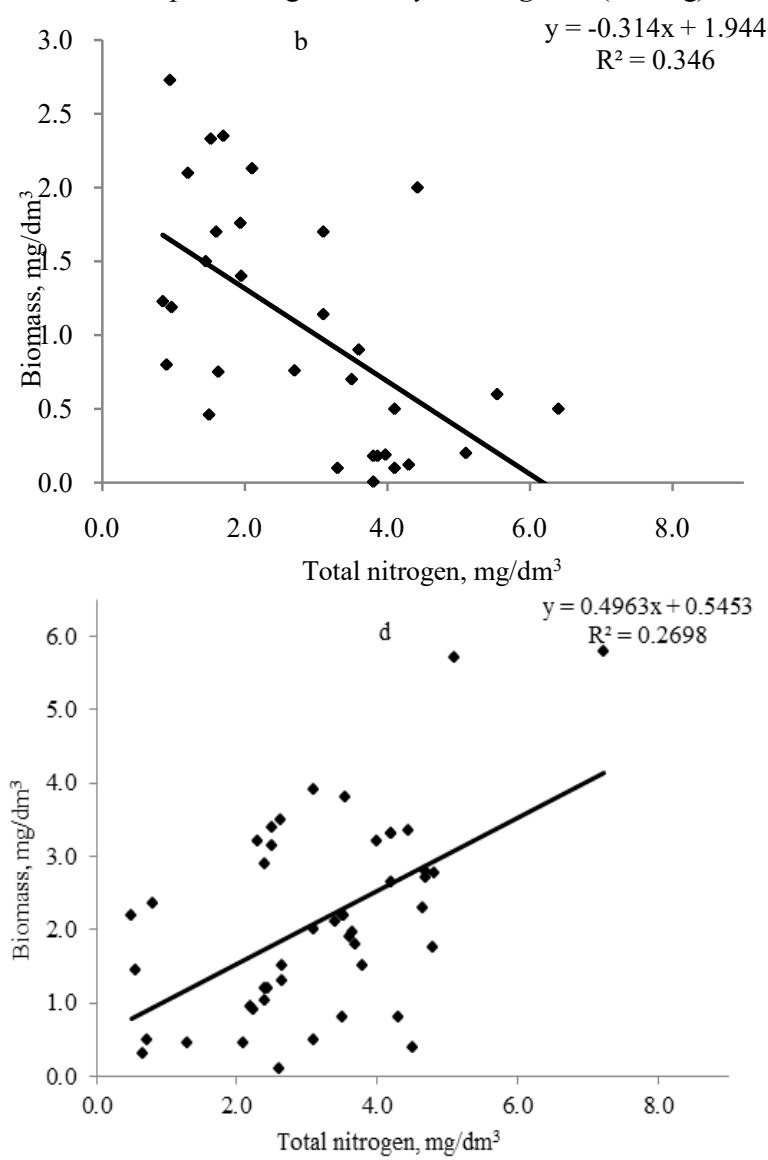

Fig. 5. The relationship between the content of total nitrogen and the phytoplankton biomass in water bodies of different types of the Ukrainian Polissia according to the results of studies in 2015-2019: $a$ - rivers, $b$-lakes, $c$ - water reservoirs, $d$-quarries

The share of dominant species and abundant species (above 50\%) decreases in the following order: rivers $\rightarrow$ water reservoirs $\rightarrow$ lakes $\rightarrow$ quarries, which is explained by the increase in monotony of living environment during the transition from lotic to lentic conditions. The comparison of lists of abundant algal species in the rivers of the Prypiat and Teterev basins showed their significant similarity $\left(K_{S}=0.52 \%\right)$. Most of the studied watercourses had 1-3 abundant species. Their number was 4-7 species in the rivers Horyn, Sluch, Ikopot, Derevychka, Hnylopiat, Zelena and Kodnianka. There were recorded 1-7 abundant species in the lakes of karst origin, but in the lakes Horokhivka and Didove, such species were absent. The comparison of water reservoirs according to abundant species composition revealed their significant similarity $\left(K_{S}=0.36-0.40\right)$. However, only species Cyclotella meneghiniana was frequently found in all water reservoirs. In general, 4-8 abundant species were recorded in water reservoirs. Water reservoirs formed at the sites of the quarries for the extraction of minerals had a common feature: the diatom algae Cyclotella meneghiniana (64-100\%) was noted as abundant specie.

On the example of the River Hnylopiat, the spatial phytoplankton discreteness along the longitudinal profile of the river determined for large rivers of Europe was confirmed. It developed under the influence of the regulation and manifests in increase in Cyanobacteria vegetation, decrease in the phytoplankton informational diversity and an increase in the number of species in the regulated areas. Decrease in species richness in lotic ecosystems occurs in the areas affected by anthropogenic pollution, including wastewater (Table 2).
Table 2

Indicators of phytoplankton growth in the Hnylopiat River sections of different types

\begin{tabular}{lcccc}
\hline \multirow{2}{*}{\multicolumn{1}{c}{ Indicators }} & \multicolumn{4}{c}{ Stations } \\
\cline { 2 - 5 } & 1 & 2 & 3 & 4 \\
\hline Number of species & 110 & 58 & 25 & 85 \\
Abundance, mln cells $/ \mathrm{dm}^{3}$ & 31.412 & 10.300 & 8.857 & 16.268 \\
Biomass, $\mathrm{mg} / \mathrm{dm}^{3}$ & 4.138 & 1.580 & 0.791 & 1.961 \\
The Shannon index, bit/mg & 1.70 & 1.79 & 1.14 & 1.68 \\
Saprobity & 1.9 & 1.9 & 2.0 & 1.5 \\
\hline
\end{tabular}

Notes: 1 - a section regulated by Berdychivske Water Reservoir, 2 - a river section below the reservoir, 3 - a section below the treatment facilities of the city of Berdychiv, 4-a section regulated by the Skraglivetsky pond.

\section{Discussion}

At the beginning of the XXI century, the scale of anthropogenic impact approached the limits commensurate with natural geochemical processes, which threatens disruption of the natural cycle of matter and energy. Natural and anthropogenic flows are interconnected, which causes difficulties in distinguishing the actual "natural" and "anthropogenic" cycles (Odum, 1986). A number of authors have shown that the changes caused by the inflow of biogens into continental waters create conditions for the process of anthropogenic eutrophication, causing the restructuring of aquatic ecosystems (Kozak et al., 2020). 

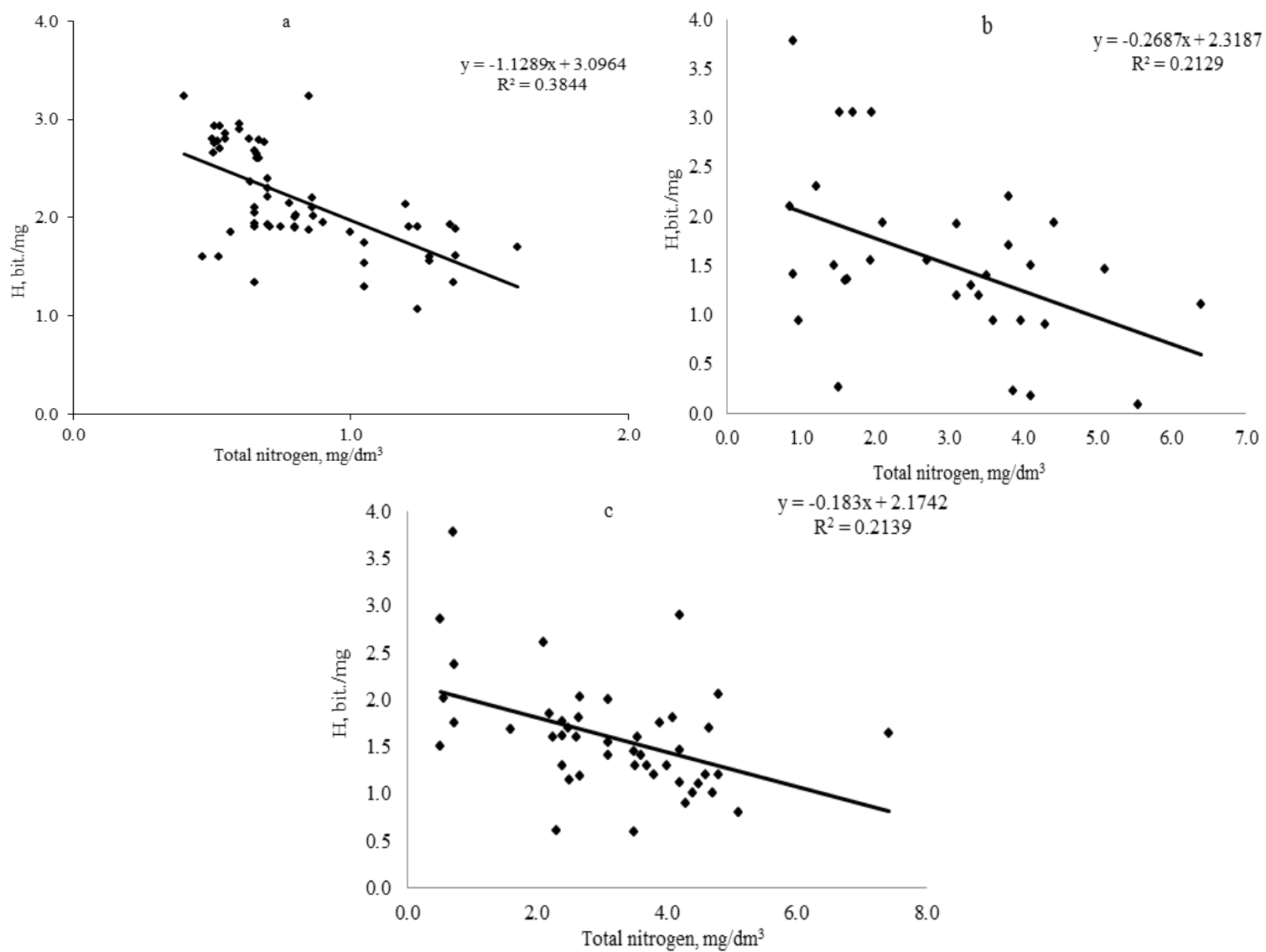

Fig. 6. The relationship between the content of total nitrogen and phytoplankton informational diversity $(\mathrm{H})$ of different types of water bodies in the Ukrainian Polissia according to the results of studies in 2015-2019: $a$-rivers, $b$-lakes, $c$ - quarries

There is also a great number of publications on the consequences of river-flow regulations, which caused changes in the hydrochemical and hydrophysical properties of waters (slowing of water exchange, decrease in the flow rate, changes in the $\mathrm{N} / \mathrm{P}$ ratio, ionic composition) and analyses of factors determining phytoplankton succession. It is shown that the growth and development of phytoplankton in rivers and reservoirs is largely controlled by the same factors as in lakes: light and temperature regimes, their periodicity, colour and transparency of waters, gas composition dynamics, ion concentration and balance, biotic interactions (Trifonova \& Pavlova, 2005; Chekryzheva, 2011; Shelyuk, 2019). However, despite the sufficient regularity of the study of particular water bodies, there is no consensus among researchers about the mechanisms, which influence phytoplankton development at that stage (Reynolds, 1988; Polimene et al., 2014; Deng et al., 2016).

In recent years, there is a growing need to use the basin approach to elucidate the patterns of reaction of the communities and their species richness to the changes in the complex of environmental factors (Shelyuk \& Shcherbak, 2018). Our multi-year research examined different types of water bodies of the Prypiat and Teteriv basins with different degrees of anthropogenic influence and determined increase in species richness of Euglenozoa as a result of organic pollution of water bodies and watercourses, decrease in the share of Charophyceae algae, which was probably a consequence of increased water mineralization. The studies confirmed spatial discreteness of phytoplankton along the longitudinal profile of the rivers, which is being developed under the influence of overregulation, and manifests in the strengthening of Cyanobacteria vegetation, reduction of phytoplankton information diversity and increase in the number of species in the regulated areas. It is shown that the decline of species richness in lotic ecosystems occurs in areas exposed to anthropogenic pollution, including due to wastewater. The research determined the patterns of phytoplankton succession in man-made water bodies formed on the sites of quarries for the extracting natural minerals such as sand, granite, and ilmenite.

The comparison of the research results obtained by the authors on quantitative indicators of phytoplankton development in the Prypiat tribu- taries and the scientific data for 1960-1963 (Radzymovsky \& Polishchuk, 1970) and 1980-1983 (Krakhmalnyy, 1986) allow us to state that the average values of phytoplankton abundance and biomass of these watercourses have approached their level recorded in the 1960s before the beginning of the reclamation of the Polissia region. At that time, the average number of plankton algae in the tributaries of the Prypiat was 3 million cells $/ \mathrm{dm}^{3}$ and the biomass was $1 \mathrm{mg} / \mathrm{dm}^{3}$. After the termination of reclamation work in the region (1980s), there was observed increase in phytoplankton number (on average up to 7 million cells $/ \mathrm{dm}^{3}$ ) and biomass (up to $14 \mathrm{mg} / \mathrm{dm}^{3}$ ). The increase in the quantitative indicators of phytoplankton development was probably caused by increase in the content of total nitrogen in rivers due to the intensification of industry and agriculture. The decrease in phytoplankton abundance and biomass over the recent decades is explained by decrease in $\mathrm{N}_{\text {inorg }} / \mathrm{P}_{\text {inorg. }}$ ratio in the river waters.

The factors contributing to a certain decrease in the concentration of inorganic forms of nitrogen may include intensive vegetation of higher aquatic plants, which is increasingly overgrowing shallow water areas, and decline in the production. Besides, one of the reasons of increase in the concentration of inorganic phosphorus is the ingress of phosphorus-containing surfactants. The changes in the taxonomic composition were as follows: diatoms, green and blue-green algae prevailed before the reclamation and green algae, diatoms, and blue-green algae dominated after the reclamation. Over the recent 15 years, Chorophyta, Bacillariophyta and Euglenozoa plants dominated. The comparison of the list of algal species identified by the authors during 2005-2019 with reports in the literature (Tsarenko et al., 2006), allowed us to identify 75 specific and infraspecific taxa, new to the Ukrainian Polissia (Table 3).

Their significant share comprises thermophilic and brackish-water species, and also polysaprobes that were not previously found in the region. We suppose that the emergence of new species for the region is a result of the changes in the hydrological and chemical regimes of water bodies and watercourses related to the regulation, drainage reclamation and the climate change. 
Table 3

New algal species for the Ukrainian Polissia

\begin{tabular}{|c|c|c|c|c|}
\hline Taxa & Rivers & Lakes & Water reservoirs & Quaries \\
\hline \multicolumn{5}{|c|}{ Cyanobacteria } \\
\hline Cyanobium diatomicola (Geitler) Komárek, J.Kopecký \& Cepák & - & - & - & + \\
\hline Cyanodictyon reticulatum (Lemmermann) Geitler & - & - & - & + \\
\hline Aphanothece salina Elenkin \& A.N.Danilov & ++ & ++ & - & - \\
\hline Gloeothece linearis Nägeli & + & - & - & - \\
\hline Aphanocapsa parietina (Nägeli ex Kützing) Nägeli & + & - & - & - \\
\hline Merismopedia minima G.Beck & - & - & - & + \\
\hline Gloeocapsa alpina Nägeli & - & - & - & + \\
\hline G. opaca Nägeli ex Kützing & - & - & - & + \\
\hline Chroococcus helveticus Nägeli & - & - & - & + \\
\hline Ch. vacuolatus Skuja & - & - & - & + \\
\hline Pseudocapsa sphaerica (Proskina-Lavrenko) Kovácik & + & - & - & - \\
\hline Chlorogloea microcystoides Geitler & + & - & - & - \\
\hline Chamaesiphon polonicus (Rostafinski) Hansgirg & - & + & - & - \\
\hline Chamaecalyx swirenkoi (Sirsov) Komárek \& Anagnostidis & - & - & - & ++ \\
\hline
\end{tabular}

Astasia torta Pringsheim

Euglena convoluta Korshikov

E. gaumei Allorge \& Lefèvre

E. minima Francé

E. splendens P.A.Dangeard

Lepocinclis glabra Drezepolski

L. globosa Francè

Phacus angustus Drezepolski

$P h$. pleuronectes var. hyalinus Klebs

Ph. pleuronectes (O.F.Müller) Nitzsch ex Dujardin

Ph. striatus Francè

Ph. zmievicus Dedusenko-Stregoleva

Trachelomonas abrupta var. minor Deflandre

T. curta f. punctata (Skvortzov) T.G.Popova

T. volvocinopsis var. punctata (Skvortzov) Bourrelly

\begin{tabular}{|c|c|c|c|c|}
\hline \multicolumn{5}{|l|}{ Euglenozoa } \\
\hline & + & - & - & - \\
\hline & ++ & + & - & - \\
\hline & + & - & - & - \\
\hline & + & - & - & - \\
\hline & + & - & - & + \\
\hline & - & - & - & + \\
\hline & ++ & ++ & +++ & - \\
\hline & ++ & - & - & - \\
\hline & + & - & - & - \\
\hline & ++ & - & - & - \\
\hline & + & - & - & ++ \\
\hline & + & - & - & - \\
\hline & + & - & - & ++ \\
\hline & ++ & - & - & - \\
\hline & + & ++ & - & + \\
\hline \multicolumn{5}{|l|}{ Ochrophyta } \\
\hline & + & + & - & + \\
\hline & + & - & - & - \\
\hline & - & - & + & - \\
\hline & + & - & - & - \\
\hline & + & - & - & + \\
\hline & + & - & - & ++ \\
\hline & +++ & ++ & ++ & ++ \\
\hline & - & - & - & + \\
\hline & + & + & - & + \\
\hline & - & + & - & - \\
\hline & + & - & - & - \\
\hline & - & + & - & - \\
\hline & - & ++ & - & - \\
\hline & + & - & - & - \\
\hline & + & + & - & - \\
\hline & + & - & - & - \\
\hline & - & + & - & - \\
\hline & + & - & - & - \\
\hline & + & ++ & - & - \\
\hline & + & - & - & - \\
\hline & - & - & + & - \\
\hline & + & - & - & - \\
\hline & + & - & - & - \\
\hline \multicolumn{5}{|l|}{ Bacillariophyta } \\
\hline & + & - & - & + \\
\hline & ++ & - & - & - \\
\hline & + & - & - & - \\
\hline & + & - & - & - \\
\hline & + & - & - & - \\
\hline & - & - & - & + \\
\hline & + & - & - & - \\
\hline & + & - & - & - \\
\hline & + & - & - & + \\
\hline & - & - & - & ++ \\
\hline & + & - & - & + \\
\hline & + & - & - & - \\
\hline & + & - & - & - \\
\hline & + & - & - & - \\
\hline & ++ & - & - & - \\
\hline & + & - & - & - \\
\hline & ++ & - & - & - \\
\hline \multicolumn{5}{|l|}{ Chlorophyta } \\
\hline & + & - & - & - \\
\hline & + & - & - & + \\
\hline & + & - & - & - \\
\hline & + & - & - & - \\
\hline \multicolumn{5}{|l|}{ Charophyta } \\
\hline & - & - & - & + \\
\hline & - & - & - & + \\
\hline
\end{tabular}

Chromulina commutata Pascher

Ch. freiburgensis Doflein

Ch. nebulosa Cienkowski

Ch. nitens Skuja

Ch. ovalis Klebs

Ch. pascheri Hofeneder

Ch. rosanoffii (Woronin) Blochmann

Chrysococcus elegans (Doflein) Bourrelly

Kephyrion boreale Skuja

$K$. circumvallatum (Schiller) Bourrelly

K. schmidii Bourrelly

K. sitta Pascher

Lepochromulina calyx Scherffel

Epipyxis cylindrica (L.Reverdin) D.K.Hilliard \& B.C.Asmund

Pseudokephyrion conicum Schiller

P. cyclindricum (Lackey) Bourrelly

$P$. ellipsoideum (Pascher) Conrad

P. entzii W.Conrad

$P$. latum (Schiller) Gerlinde Schmid

P. ruttneri (Schiller) Gerlinde Schmidt

Uroglena botrys (Pascher) Conrad

U. glabra O.M.Matvienko

Tetraplektron torsum (W.B.Turner) Dedusenko-Shchegoleva

Fragilaria nanana Lange-Bertalot

Fragilariforma virescens var. elliptica Hustedt

$F$. virescens var. oblongella (Grunow) E.Y.Haworth \& M.G.Kelly

Catacombas gaillonii (Bory) D.M.Williams \& Round

Diatoma vulgaris var. ovalis (Fricke) Hustedt

Mastogloia angulata F.W.Lewis

M. smithii Thwaites ex W.Smith

Achnanthes brevipes C.Agardh.

A. coarctata (Brébisson ex W.Smith) Grunow

Cocconeis maxima (Grunow) H.Peragallo \& M.Peragallo

C. scutellum Ehrenberg

Parlibellus delognei (Van Heurck) E.J.Cox

Diadesmis gallica W.Smith

Pinnularia oriunda Kramme

Navicula angusta Grunow

Gyrosigma distortum (W.Smith) Griffith \& Henfrey

Amphora obtusa W.Gregory

Gongrosira schmidlei P.G.Richter

Hormotilopsis gelatinosa Trainor \& Bold

Hariotina polychordum (Korshikov) E. Hegew

H. reticulata P.A. Dang.

Cylindriastrum capitulum (Brébisson) Palamar-Mordvintseva

Staurastrum sexcostatum subsp. productum West

Notes: "-"- the species was not found in water bodies;"+" - the species was found in 1-25\% of water bodies of a certain type; " ++" - the species was found in $26-50 \%$ of water bodies of a certain type;" +1+"- the species was found in $51-100 \%$ of water bodies of a certain type. 
On the example of mesotrophic Denyshivske Water Reservoir and eutrophic Zhytomyrske Water Reservoir, it was shown that during limnogenesis, due to the creation of small water reservoirs, the phytoplankton succession was accompanied by increase in the role of blue-green algae in the formation of species richness. It was determined that before the regulation, several years before the creation of Denyshivske Water Reservoir (1973), the leading divisions in this area of the river were green algae and diatoms, and singularly occurring blue-green algae, according to Dohadina (1975), were random species brought from stream pools. The research conducted in 2005-2019 revealed the leading role of blue-green algae in the phytoplankton abundance formation $(90-96 \%$ of the total number of cells), the biomass formation was dominated by the divisions Miozoa (25-37\% of the total biomass), Bacillariophyta (10-31\%), Cyanobacteria (12-44\%), Chlorophyta (9-11\%). At the present stage of development of the water reservoir ecosystem, there is a tendency towards a decrease in phytoplankton abundance and biomass. At the same time, the share of representatives of Cyanobacteria and Euglenozoa in the formation of phytoplankton quantitative indicators in the water reservoir increased.

In contrast to Denyshivske Water Reservoir, the average values of phytoplankton abundance and biomass in the Zhytomyrske Water Reservoir did not change during the study period. The maximums of abundance and biomass in different study periods were recorded in summer in the Denyshivske Water Reservoir. At the present stage, there is a shift in the maximums of biomass of algal cells from summer to autumn in Zhytomyrske Water Reservoir.

During the study, increase in the species richness of Chlorophyta, Euglenozoa, and Ochrophyta occurred both in the mesotrophic Denyshivske Water Reservoir and the eutrophic Zhytomyrske Water Reservoir. We observed insignificant rearrangements in the phytoplankton structure at the class level and more noticeable at the level of orders, families and genera. There was a decrease in the species saturation of genera Navicula (also Closterium Nitzsch et Ralfs in Denyshivske Water Reservoir), the species content of genus Chlamydomonas increased (an increase in the floristic role of genera Kephyrion, Pseudokephyrion and Dictyosphaert in the Denyshivske Water Reservoir and Euglena, Cyclotella and Peridinium in the the eutrophic Zhytomyrske Water Reservoir). The generic coefficients and the saturation of species with intraspecific taxa slightly increased in the water reservoirs. At the same time, most of the large water reservoirs of the rivers Dnipro and Volga tend to simplify the phytoplankton taxonomic structure with age (Scherbak, 1999). The reason for maintaining the structural complexity of the communities can be lateral flow and a significant intensity of adaptation processes of algal communities of small water reservoirs, characterized by the prevalence of shallow water areas with their characteristic increased rate of production processes.

The changes in information diversity over the 15 -year period of research in water reservoirs varied: the decrease was recorded in the eutrophic Zhytomyrske Water Reservoir and no noticeable changes in the Shannon index were observed in mesotrophic Denyshivske Water Reservoir.

Increase in the share of thermophilic forms $(7.8 \%$ to $10.1 \%$ in the Denyshivske Water Reservoir, and $8.3 \%$ to $11.2 \%$ in the Zhytomyrske Water Reservoir from) and decrease in cold-loving forms (17.9\% to 8.9\% in the Denyshivske Water Reservoir and $16.7 \%$ to $0.2 \%$ in the Zhytomyrske Water Reservoir) were noted, which is probably the response of planktonic algae to the climate change. The average water temperature in the water reservoirs for the growing season from 2005 to 2019 increased by $1.15^{\circ} \mathrm{C}$. The share of thermophilic forms in the river ecosystems increased by $3.4 \%-17.5 \%$ (Shelyuk, 2017).

In general, the noticeable increase in the species richness of Euglenozoa in the aquatic ecosystems of the Ukrainian Polissia resulted from organic pollution of the water bodies and watercourses and also lecrease in the share of Charophyceae algae, which is probably a consequence of increase in water salinity. Seasonal changes in the composition of algae are not clearly expressed, and there were observed no noticeable impoverishment of the dominant complex of species in autumn and enrichment in summer typical for the watercourses in Europe (Shcherbak, 1999).

Recently, there has been a growing interest to invasive species, their invasion, distribution and naturalization into habitats not typical for them (Paerl \& Huisman, 2009). The studies revealed that increased biological pollution may lead to disturbances in the diversity of native flora and fauna, trophic interactions of their components, and, as a result, to changes in the productivity of aquatic ecosystems.

Currently, 16 species of diatom invaders in the Great Lakes are known (Ricciardi \& Cohen, 2007), brackish-aquatic species not previously found in the phytoplankton of unregulated rivers in Europe were discovered (Korneva, 2006; Alexandrov et al., 2007), which at this stage determine the structure of planktonic algocenoses of aquatic ecosystems. Our studies revealed the appearance of 75 algal species in the aquatic ecosystems of the Ukrainian Polissia, which were not previously found in this region according to Tsarenko et al. (2006). A significant share of these species is confined to the southern regions, which indicates the process of algal invasiveness and the spread of thermophilic forms of algae in the temperate climatic zone, as well as brackish-water forms due to the growth of water mineralization. We consider that changes in the hydrological and chemical regimes of water bodies and watercourses, related to the regulation and the climate change, were the trigger for the emergence and adaptation of invading algae to new places of existence. The most important factor determining the changes in the hydrobiota structure of the Ukrainian Polissia was large-scale drainage reclamation. Probably, global warming and the expected increase in the salinity of fresh waters may lead not only to the expansion of halophiles and thermophilic algal species, but also to decrease in the number and even the disappearance of a number of oligotrophic species, including Chrysopyxis pitschmannii $\mathrm{H}$. Ettl, a species known in the world only from three localities, including the floodplain of the River Zholobnytsia (Karustyn et al., 2013).

\section{Conclusion}

In the analysis of the taxonomic composition, information diversity, quantitative indicators of phytoplankton growth and its temporal dynamics, we determined the patterns of development of the main autotrophic link of aquatic ecosystems in the gradient of dependence on the anthropogenic load - from natural waters to significantly altered and man-made water bodies, as well as the climate changes. The greatest abundance of phytoplankton species was found in the water reservoirs. The average number of species decreased in the following order: water reservoirs $(118.8 \pm 2.8) \rightarrow$ rivers $(106.8 \pm 5.3) \rightarrow$ quarries $(98.7 \pm 3.0) \rightarrow$ lakes $(58.4 \pm 2.4)$. The studied water bodies were dominated by Chlorophyta, Bacillariophyta, Euglenozoa and Cyanobacteria. No less than 75 algal species were identified for the first time in the Ukrainian Polissia, a significant part of which are halophiles in relation to water salinity and thermophilic forms. This indicates the process of algal invasiveness due to increase in water salinity and the distribution of thermophilic forms of algae in the temperate climatic zone.

The average phytoplankton biomass over the growing seasons decreased in the following order: water reservoirs $\left(2.88 \pm 0.37 \mathrm{mg} / \mathrm{dm}^{3}\right) \rightarrow$ rivers $\left(2.30 \pm 5.29 \mathrm{mg} / \mathrm{dm}^{3}\right) \rightarrow$ quarries $\left(1.95 \pm 0.15 \mathrm{mg} / \mathrm{dm}^{3}\right) \rightarrow$ lakes $\left(1.36 \pm 0.15 \mathrm{mg} / \mathrm{dm}^{3}\right)$. The highest informational diversity was typical for river ecosystems, its decrease occurred in the following order: rivers $(1.89 \pm 0.02 \mathrm{bit} / \mathrm{mg}) \rightarrow$ water reservoirs $(1.76 \pm 0.03 \mathrm{bit} / \mathrm{mg}) \rightarrow$ lakes $(1.64 \pm 0.05 \mathrm{bit} / \mathrm{mg}) \rightarrow$ quarries $(1.62 \pm 0.10 \mathrm{bit} / \mathrm{mg})$. Increase in the total nitrogen content decreased $\mathrm{H}(\mathrm{r}=-0.36--0.67)$. The value of informational diversity was determined by the content of phosphorus and phosphates in the water reservoirs $(r=-0.73)$. The average values of the saprobity index increased in the following order: lakes $(1.73 \pm 0.36) \rightarrow$ quarries $(1.74 \pm 0.20) \rightarrow$ water reservoirs $(1.77 \pm 0.06) \rightarrow$ rivers $(1.85 \pm 0.06)$.

The high intensity of vegetation of the algal communities with dominance of Chlorophyta, Bacillariophyta and representatives of Cyanobacteria and Euglenozoa divisions in the man-made water bodies formed at the sites of flooded mining quarries is an important mechanism of the succession of the autotrophic link, which determines the development of aquatic ecosystems of a new type. In the aquatic ecosystems with high trophic status, there was a shift in the maxima of phytoplankton biomass from spring - summer to late summer - early autumn, which was caused by changes in the water temperature over the recent decades and an extension of the growing season. The obtained data can be used for predicting scenarios of changes in the autotrophic link under the influence of natural and anthropogenic factors, the development of precautions against degradation of aquatic ecosystems; the determined patterns of succession of 
algal communities in man-made water bodies created at the sites of quarries may become the basis for developing recommendations for their natural renewal with the aim of further use for recreation, fish farming and technical water supply.

\section{References}

Afanasyev, S. A. (2002). Development of European approaches to biological assessment of the state of hydroecosystems and their application to the monitoring of Ukrainian Rivers. Hydrobiological Journal, 38(4), 130-139.

Alexandrov, B., Boltachev, A., Kravchenko, T., Lyashenko, A., Son, M., Tsarenko, P., \& Zhukinsky, V. (2007). Trends of aquatic alien species invasions in Ukraine. Aquatic Invasions, 2(3), 215-242.

Barinova, S. (2011). Algal diversity dynamics, ecological assessment, and monitoring in the river ecosystems of the eastern Mediterranean. Nova Science Publishers, New York.

Barinova, S. S., Klochenko, P. D., \& Belous, Y. P. (2015). Algae as indicators of the ecological state of water bodies: Methods and prospects. Hydrobiological Journal, 51(6), 3-21.

Chekryzheva, T. A. (2011). Phytoplankton of the lakes of the Shuya River basin (Kareliya Republic, Russia). Hydrobiological Joumal, 47(3), 21-29.

Cupertino, A., Gücker, B., Rückert, G., \& Figueredo, C. C. (2019). Phytoplankton assemblage composition as an environmental indicator in routine lentic monitoring: Taxonomic versus functional groups. Ecological Indicators, 101, 522-532.

Deng, J., Qin, B., Sarvala, J., Salmaso, N., Zhu, G., Ventelä, A.-M., Zhang, Y., Gao, G., Nurminen, L., Kirkkala, T., Tarvainen, M., \& Vuorio, K. (2016). Phytoplankton assemblages respond differently to climate warming and eutrophication: A case study from Pyhäjärvi and Taihu. Journal of Great Lakes Research, 42(2), 386-396.

Dohadina, T. V. (1975). Kharakterystyka al'hoflory riznykh dilyanok r. Teterev [Characteristics of the algaeflora of different parts of the Teteriv River]. Ukrainian Botanical Journal, 32(1), 19-23 (in Ukrainian).

Kapustin, D., Tsarenko, P., Partyka, L., \& Virchenko, V. (2013). Fitoriznomanittya Polis'koho pryrodnoho zapovidnyka: Vodorosti, mokhopodibni, sudynni roslyny [Phytodiversity of Polissya Nature Reserve: Algae, moss-like, vascular plants]. Interservice, Kyiv (in Ukrainian).

Klimaszyk, P., \& Gołdyn, R. (2020). Water quality of freshwater ecosystems in a temperate climate. Water, 12, 2643.

Korneva, L. G. (2014). Invasions of alien species of planktonic microalgae into the fresh waters of Holarctic (review). Russian Journal of Biological Invasions, 5(2), 65-81.

Kozak, A., Budzynska, A., Dondajewska-Pielka, R., Kowalczewska-Madura, K., \& Gołdyn, R. (2020). Functional groups of phytoplankton and their relationship with environmental factors in the restored Uzarzewskie Lake. Water, 12, 313.

Linnik, P. N., Zhezherya, T. P., Shelyuk, Y. S., \& Zhezherya, V. A. (2016). Peculiarities of chemical elements migration and phytoplankton development in the reservoirs of the Teterev River. Hydrobiological Journal, 52(5), 93-107.

Mineeva, N. M., Shchur, L. A., \& Bondarenko, N. A. (2012). Phytoplankton functioning in large freshwater systems differing in their resources. Hydrobiological Journal, 48(5), 19-35.

Odum, Y. (1986). Ekologiya [Ecology]. Mir, Moscow (in Russian).

Omar, W. M., \& Makhlough, A. (2014). Water quality of tropical reservoir based on spatio-temporal variation in phytoplankton composition and physico-chemical analysis. International Journal of Environmental Science and Technology, 12(7), 1735-1472.
Paerl, H. W., \& Huisman, J. (2009). Climate change: A catalyst for global expansion of harmful cyanobacterial blooms. Environmental Microbiology Reports, 1(1), 27-37.

Polimene, L., Brunet, C., Butenschön, M., Martinez-Vicente, V., Widdicombe, C. Torres, R., \& Allen, J. (2014). Modeling a light-driven phytoplankton succession. Joumal of Plankton Research, 36(1), 214-229.

Radzymovsky, D. O., \& Polishchuk, V. V. (1970). Plankton r. Pryp'yat' [Plankton of the Prypiat River]. Naukova Dumka, Kyiv (in Ukrainian).

Reynolds, C. S., Huszar, V., Kruk, C., Naselli-Flores, L., \& Melo, S. (2002). Towards a functional classification of the freshwater phytoplankton. Journal of Plankton Research, 24(5), 417-428.

Ricciardi, A., \& Cohen, J. (2007). The invasiveness of an introduced species does not predict its impact. Biological Invasions, 9, 309-315.

Rodrigues, L. C., Pivato, B. M., Vieira, L. C., Bovo-Scomparin, V. M., Bortolini, J. C., Pineda, A., \& Train, S. (2018). Use of phytoplankton functional groups as a model of spatial and temporal patterns in reservoirs: A case study in a reservoir of Central Brazil. Hydrobiologia, 805(1), 147-161.

Romanenko, V. D. (2006). Metody hidroekolohichnykh doslidzhen' poverkhnevykh vod [Methods of hydroecological research of surface waters]. Logos, Kyiv (in Ukrainian).

Santana, L. M., Crossetti, L. O., \& Ferragut, C. (2017). Ecological status assessment of tropical reservoirs through the assemblage index of phytoplankton functional groups. Brazilian Joumal of Botany, 40, 695-704.

Shcherbak, V. I. (1999). Structural and functional characteristics of phytoplankton in the water bodies within the exclusion zone of the Chernobyl Nuclear Power Station. Hydrobiological Journal, 35(5), 158-174.

Shcherbak, V. I., \& Semenyuk, N. Y. (2009). Use of phytoplankton for the assessment of the ecological state of water bodies of the megalopolis according to the EU Water Framework Directive - WFD (2000/60/EC). Hydrobiological Journal, 45(2), 24-34.

Shelyuk, Y. S. (2017). The bio-indicative analysis of species composition of phytoplankton of the Pripyat River tributaries (Ukraine). International Joumal on Algae, 19, 147-162.

Shelyuk, Y. S. (2019). Regularities of primary production formation in river ecosystems (the basins of the Pripyat and Teteriv Rivers, Ukraine). Hydrobiological Joumal, 55(4), 38-54.

Shelyuk, Y. S., \& Shcherbak, V. I. (2018). Phytoplankton structural and functional indices in the rivers of the Pripyat and Teterev basins. Hydrobiological Journal, 54(3), 10-23.

Sladeček, V. (1986). Diatoms as indicators of organic pollution. Acta Hydrochimica et Hydrobiologica, 14(5), 555-566.

Sorensen, T. A. (1948). Method of establishing groups of equal amplitude in plant sociology based on similarity of species content. Kongelige Danske Videnskabernes Selskabs Biologicheske Skrifter, 5(4), 46-71.

Trifonova, I. S., \& Pavlova, O. A. (2005). Structure and succession of phytoplankton in urban water bodies of St.-Petersburg. Hydrobiological Journal, 41(3), 3-12.

Tsarenko, P. M., Wasser, S. P., \& Nevo, E. (2006). Algae of Ukraine: Diversity, nomenclature, taxonomy, ecology and geography. Cyanoprocaryota, Euglenophyta, Chrysophyta, Xanthophyta, Raphidophyta, Phaeophyta, Dinophyta, Cryptophyta, Gaucocystophyta, and Rhodophyta. Ganter Verlag, Ruggell.

Tuz, Y. (2012). Bahatorichni sezonni zminy temperatury na terytoriyi Ukayiny [Manyyear seasonal change of air temperature on the territory of Ukraine]. Geography and Tourism, 2, 269-275 (in Ukrainian).

Xuehual, L., Xiaofei, L., Lin, W., \& Zhaoxue, T. (2019). Diversity in phytoplankton communities: A field test of the intermediate disturbance hypothesis. Ecological Engineering, 129, 54-60. 